\title{
Pengaruh Virgin Coconut Oil (VCO) terhadap Karakteistik Fisik, Kimia dan Mikrobiologi Strawberry (Fragaria $x$ ananassa) Selama Penyimpanan
}

\author{
The Effect of Virgin Coconut Oil (VCO) on Physical, Chemical and Microbiological Characteristics of Strawberry \\ Fruit during Storage
}

\author{
Lintang Sawitri Nugraheni, Rohula Utami, Siswanti \\ Program Studi IImu Teknologi Pangan, Fakultas Pertanian, Universitas Sebelas Maret, Jl. Ir. Sutami No.36 Kentingan, \\ Surakarta, 57126, Jawa Tengah, Indonesia \\ *E-mail: lintangsawitri12@student.ac.uns.id
}

Diterima: 2 Januari 2020; Disetujui: 8 Juni 2020

\begin{abstract}
ABSTRAK
Strawberry merupakan salah satu buah hortikulura yang mudah rusak (perisable), sehingga memiliki umur simpan yang pendek. Kerusakan strawberry disebabkan karena pembusukan akibat pengaruh mekanis maupun mikrobioogi. Penurunan kualitas buah dapat ditandai dengan penurunan susut bobot, kelayuan, penurunan firmness, dan penurunan nilai gizi. Pengawetan strawberry segar sangat diperlukan untuk mempertahankan karakteristik pada strawberry. Salah satu cara mengurangi kerusakan dengan metode pelapisan (coating). Pada penelitian ini dilakukan usaha untuk memperpanjang umur simpan strawberry dengan menggunakan VCO. Penelitian ini dilakukan untuk mengetahui karakteristik fisik, kimia, mikrobiologi dan metode pengaplikasian VCO yang efektif untuk memperpanjang umur simpan strawberry. Rancangan penelitian yang digunakan adalah Rancangan Acak Lengkap (RAL) dengan satu faktor yaitu metode pengaplikasian VCO (kontrol, dipping, dan spraying). Data karakteristik dianalisis secara statistik menggunakan one way ANOVA. Jika data menunjukkan hasl beda nyata antar perlakuan maka dilanjutkan uji DMRT pada $\alpha=0,05$. Hasil penelitian menunjukan bahwa VCO dapat mempertahankan susut bobot, warna, firmness, kadar air, TPT, Vitamin C, pH, TAT dan menurunkan total mikroba strawberry selama penyimpanan. Metode pengaplikasian Virgin Coconut Oil (VCO) dipping dan spraying efektif dalam menghambat pertumbuhan mikroba pada strawberry selama 12 hari penyimpanan.
\end{abstract}

Kata kunci: strawberry; dipping; pengawetan, spraying; VCO

\begin{abstract}
Strawberry is one of the perishable Horticulum (perisable), so it has a short shelf life. Strawberry damage caused by decay due to mechanical influences and microbioogi. Deterioration in the quality of fruit can be characterized by decreased shrinkage weight, kelayuan, decreased firmness, and decreased nutritional value. Fresh strawberry pickling is indispensable to retain the characteristics of strawberry. One way to reduce damage by coating method. In this research, efforts to extend the life of strawberry Save using VCO. This research is conducted to determine the physical characteristics, chemistry, microbiology and application method of effective VCO to extend the strawberry shelf life. The research plan used is complete random plan (RAL) with one factor that is application method of VCO (control, dipping, and spraying). The characteristic Data is analyzed statistically using one way ANOVA. If the data shows a noticeable difference between the treatment then proceed to test $D M R T$ at $\alpha=0.05$. The results showed that VCO can maintain the shrinkage weight, color, firmness, moisture content, TPT, Vitamin C, pH, TAT and lower total of strawberry microbes during storage. Application method of Virgin Coconut Oil (VCO) is being dipping and spraying effectively to inhibit microbial growth in strawberry during 12 days storage.
\end{abstract}

Keywords: strawberry; dipping; pickling; spraying; VCO

\section{PENDAHULUAN}

Buah strawberry banyak dikonsumsi dalam bentuk segar maupun dalam bentuk olahan seperti sirup, selai dodol, manisan, dan bahan tambahan pada kue. Buah strawbery (Fragaria $x$ ananassa) jika dikonsumsi segar memiiki kulit yang bewarna merah segar dengan bentuk dan ukuran yang seragam. Menurut USDA nutrition fact (2018) kandungan buah strawbery dalam $100 \mathrm{~g}$ yaitu 32 kalori energi, protein $0,67 \mathrm{~g}$, lemak $0,3 \mathrm{~g}$, karbohidrat 7,68 g, kalsium $16 \mathrm{mg}$, fosfat $24 \mathrm{mg}$, besi $0,8 \mathrm{mg}$, vitamin A $12 \mathrm{IU}$, vitamin B $0,047 \mathrm{mg}$, vitamin C 58,8 mg dan 90,95 g air. Menurut Kurnia (2005), konsumsi 8 buah strawberry dalam sehari atau 50 kalori dalam sehari dapat meningkatkan kadar fosfat dalam darah, menurunkan tekanan sistolik darah, membantu meningkatkan fungsi ingatan dan mengatasi peradangan sendi atau reumatik.

Strawberry merupakan buah yang mudah rusak (perisable). Jika dipetik dalam kondisi matang dan disimpan dalam suhu ruang hanya bertahan 3-4 hari (Hanif, 2014). Buah setelah dipanen dan tidak langsung ditangani akan cepat mengalami pembusukan. Kerusakan buah dapat menyebabkan penurunan kualitas dan nilai ekonomi pada buah. Buah-buahan lebih disukai untuk dikonsumsi dalam keadaan segar. Pengawetan pada buah strawberry segar sangat diperlukan untuk mempertahankan karakteristik pada buah strawberry. Pengawetan menggunakan bahan yang sehat dan aman saat ini terus meningkat sehingga perlu dilakukan adanya pengembangan penggunaan bahan pengawet alami. 
Pengawetan menggunakan bahan alami sudah banyak diterapkan pada buah dan sayur terutama buah strawberry. Coating oil merupakan salah satu bahan pengawet yang dapat digunakan pada buah dan sayur karena ramah lingkungan. Coating berupa oil dapat digunakan untuk mengurangi respirasi, memperpanjang umur simpan serta meningkatkan penampilan menjadi lebih mengkilap (Kamboj dan Amarjeet, 2018). Menurut Mahajan et al (2018), melaporkan bahwa coating berbahan lipid dapat menghambat terjadinya respirasi pada buah serta menutupi pori-pori pada buah. Sehingga $\mathrm{O}_{2}$ disekitar tidak dapat masuk ke dalam jarigan buah. Respirasi merupakan proses metabolisme yaitu $\mathrm{O}_{2}$ diserap dan digunakan untuk proses pembakaranyang menghasilkan energi dan sisa pembakaran dalam bentuk $\mathrm{CO}_{2}$ dan air (Pantastico, 1989).

Sumber minyak nabati seperti parraffin oil, mineral oil, castor oil, acetylated monoglycerides, minyak kacang, minyak jagung dan minyak kedelai dapat digunakan atau dapat dikombinasi dengan bahan pelapis yang lain sebagai pelapis produk makanan (Kore et al., 2017),. Pelapisan minyak (coating oil) dengan menggunakan mineral oil pernah diterapkan terbukti selama 18 hari dapat mengurangi kelembaban sebesar $3,2 \%$, selain itu dapat mempertahankan firmness dan kesegaran paprika (Lerdthanangkul and John, 1996). Penggunaan edible oil sebagai pelapis juga terbukti dapat memperpanjang umur simpan dan kualitas buah jambu biji. Buah jambu biji menggunakan olive oil sebagai pelapis dapat memperpanjang umur simpan selama 26 hari pada suhu dingin dan 16 hari suhu ruang (Singh et al., 2017).

Salah satu coating oil adalah VCO (Virgin Cocconut Oil). VCO mengandung $\pm 53 \%$ asam laurat dan sekitar $0,7 \%$ asam kaproat. VCO memilik sifat tidak mudah tengih, bewarna jernih dan tidak bewarna namunpada suhu refri akan berbentuk padat dan bewarna putih. VCO tiak mudah tengi karena mengandung anioksian alami daritumbuhan yang merupakan senyawa flavonoid, tokoverol dan asam oeganik. Minyak kelapa memiliki kamdngan tokoferol dan karoten. Tokoferol memiliki banyak ikatan rangkap yang mudah dioksidasi sehingga akan melindungi lemak dari oksidasi (Winano, 2004).

Asam laurat dan asam kaproat merupakan asam lemak jenuh rantai sedang yang biasa disebut Medium Chain Fatty Acidatau MCFA dan bersifat antimikroba (anti bakteridan anti jamur) (Andi, 2005). Senyawa monolaurin yang dihasilkan dari asam laurat dapat mematikan beberapa jenis bakteri seperti Staphylococcus aureus dan Helieobacterpylori (bakteri penyebab sakit maag) (Rindengan, 2006). Virgin Cocconut Oil (VCO) dapat menghambat bakteri gram positif seperti Staphyllococcus aureus, S.epidermis, Mycobacterium tuberculosis, Nocardia asteroids, Salmonella typhimurium, dan Helicobacter pylori (Widiyanti, 2015). Coating oil menggunakan bahan VCO pernah diterapkan oleh Bisen at all (2012) untuk memperpanjang umur simpan kagzi lime. Pelapisan mengunakan VCO dapat memperpanjang umur simpan kagzi lime selama 18 hari pada suhu ruang $\left(25-30^{\circ} \mathrm{C}\right)$ dengan $\mathrm{RH} 60-70 \%$.

Pengaplikasian dengan metode spraying menghasilkan pelapis yang homogen sehingga aditif antimikroba yang ada dapat menyebar dengan cepat kepermukaan yang dilapisi, Selain itu pengaplikasian dengan metode spraying lebih cepat dan efisien (Valdes et al, 2017). Sedangkan metode pengaplikasian pencelupan (dipping) teknik ini biasanya digunakan pada produk seperti daging, ikan, buah dan sayuran yang memiliki permukaan tidak rata. Teknik ini memiliki kelemahan, produk yang telah dicelup akan menyisakan bahan coating dan dibiarkan terbuang (Krochta, 1992). Tujuan dari penelitian ini adalah untuk mengetahui pengaruh VCO terhadap karakteristik fisik, kimia dan mikrobiologi buah strawberry (Fragaria $x$ ananassa) selama penyimpanan, serta metode pengaplikasian VCO yang efektif ntuk menghambat pertumbuhan mikroba pada buah strawberry (Fragaria $x$ ananassa).

\section{METODE}

\section{Bahan dan Peralatan}

Bahan yang digunakan adalah strawbrry varietas Kalibert (Ciwidey, Bandung). Kriteria strawberry yang dipilih mengacu pada penelitian Garcia et al, (2010) dengan parameter tingkat kematangan buah $\pm 75 \%$, warna kulit buah hijau kemerahan, ukuran seragam, tidak adanya infeksi jamur dan kerusakan fisik. Virgin Coconut Oil (VCO) yang digunakan diperoleh dari Koperasi Wanita Srikandi di Purworejo. Bahan yang digunakan dalam penelitian ini yaitu mika plastik (PET punnet), kertas alas, aquadest, larutan iodin 0,01 N (Merck), larutan amilum 1\%, agar PCA, larutan garam fisiologis, indikator $\mathrm{PP}, \mathrm{NaOH} 0,1 \mathrm{~N}$. sedangkan peralatan yang digunakan dalam penelitian diantaranya neraca analitik (Ohaus), blender (quantum) gelas beker 250 $\mathrm{ml}$, color analyzer (Lutron RGB-1002), texture analyzer, kurs, hand refractometer (ATAGO), pH meter (Hanna-H198103), alat titrasi, alat uji TPC.

\section{Tahapan Penelitian}

Pemilihan strawberry dengan tingkat kematangan $\pm 75 \%$ dengan ciri warna kulit buah hijau kemerahan, kemudian dilakukan penyortiran berdasarkan parameter yaitu ukuran seragam, tidak lecet atau memar, dan tidak terserang penyakit (Garcia et al., 2010). Buah yang telah disortir kemudian di kemas mika dan diletakkan di dalam keranjang kering. Buah strawberry dberi 3 perlakuan yaitu kontrol, dipping dan spraying. Untuk perlakuan dipping VCO murni dimasukkan dalam wadah atau baskom, kemudian strawberry yang telah disortir kemudian dicelupkan dalam baskom yang berisi VCO selama 10-15 detik, kemudian di tiriskan. Sedangka perlakuan spraying, VCO murni dimasukkan dalam wadah semprot sebanyak $15 \%$ dari berat total buah,kemudian VCO disemprotkan ke buah strawberry. Strawberry ditempatkan pada kemasan mika yang telah dilubangi dahulu menggunakan perforator kertas dengan diameter lubang 0,6 cm sebanyak 4 buah, lubang berada di tengah tengah tutup mika. Kemudian buah di simpan di suhu refrigenerator $\left(10 \pm 2^{\circ} \mathrm{C}\right)$ selama 12 hari.

\section{Teknik Analisis}

1. Uji Susut Bobot (AOAC, 2005), Metode gravimetric yaitu berdasarkan persentase berat bahan sejak awal sampai akhir penyimpanan.

\section{Uji Warna (Agustiningrum dkk., 2012)}

Menggunakan color analyzer PCE-RGB yang mengukur indikator warna tingkat kemerahan, kehijauan, dan kebiruan. Jika indikator warna yang ditunjukkan display semakin rendah atau menjauhi angka 1023 (nilai kalibrasi) maka warna semakin gelap.

3. Uji Firmnes (AOAC, 1984)

Menggunakanalat hardness tester dimana penggunaannya alat diletakkan secara vertikal tepat di atas bagian pangkal, tengah, dan ujung buah yang kemudian ditekan hingga mengenai permukaan kulit buah sampai tanda batas.

4. Uji Kadar Air (AOAC, 2005) 
Pengujian menggunakan kadar air dilakukan dengan pengambilan sampel sebanyak $1 \mathrm{gram}$ dimasukkan ke dalam oven dengan suhu $105^{\circ} \mathrm{C}$ selama 8 jam, lalu ditimbang. Kemudian kadar air dihitung dengan rumus:

Kadar air $=\frac{\mathrm{w}}{\mathrm{W} 1} \times 100$

Keterangan :

$\mathrm{W}$ = bobot sampel segar - bobot sampel kering (gram) $\mathrm{W} 1$ = bobot sampel segar (gram)

5. Uji TPT (Total Padatan Terlarut) (AOAC, 1990)

Menggunakan refractometer Atago yaitu meneteskan 1-2 tetes bagian cairan dari buah Strawberry yang telah dihancurkan kepada prisma refractometer. Kemudian dilakukan pembacaan nilai total padatan terlarut yang dinyatakan dengan ${ }^{0}$ brix.

6. Uji Vitamin C (AOAC, 2005)

Sampel buah Strawberry sebanyak $10 \mathrm{~g}$ slurry dimasukkan kedalam labu takar dan ditambahkan aquades hingga $100 \mathrm{ml}$, dihomogenisasi. Kemudian disaring dan filtrat diambil $25 \mathrm{ml}$. Kemudian dimasukkan kedalam erlenmeyer ditambah $1 \mathrm{ml}$ larutan amilum $1 \%$. Kemudian titrasi dengan larutan iodin standar 0,01 N sampai larutan berwarna biru.

7. Uji pH (AOAC, 2012)

Mengunakan $\mathrm{pH}$ meter, dimana 5 gr slurry Strawberry ditambahkan sampai $50 \mathrm{ml}$ aquades, kemudian dihomogenisasi dan di ukur dengan mencelupkan $\mathrm{pH}$ meter ke dalam gelas yang berisi sampel pada suhu ruang. $\mathrm{pH}$ meter dikalibrasi terlebih dahulu dengan menggunakan buffer 4 dan 7 sebelum pengukuran.

8. Uji TAT (Total Asam Terlarut) (AOAC, 2005)

Sampel buah Strawberry sebanyak $10 \mathrm{~g}$ slurry dimasukkan kedalam labu takar dan ditambahkan aquades hingga $100 \mathrm{ml}$, dihomogenisasi. Kemudian disaring dan filtrat diambil $25 \mathrm{ml}$. Kemudian dimasukkan kedalam erlenmeyer ditambah 3 tetes indikator pp kemudian dititrasi dengan $\mathrm{NaOH} 0,1 \mathrm{~N}$ sampai berwarna merah jambu.

\section{Uji TPC (Fardiaz, 1993).}

$1 \mathrm{~g}$ slurry Strawberry ditambahkan $9 \mathrm{ml}$ larutan fisiologis steril, dihomogenisasi sehingga didapat pengenceran $10^{-1}$. Pengenceran $10^{-2}$ dibuat dengan memasukkan $1 \mathrm{ml}$ sampel dari pengenceran $10^{-1} \mathrm{ke}$ dalam $9 \mathrm{ml}$ larutan fisiologis. Dengan cara yang sama dibuat seri pengenceran $10^{-3}, 10^{-4}, 10^{-5}$. Kemudian inokulasi sampel pada media. Sebanyak $1 \mathrm{ml}$ larutan sampel dimasukkan kedalam cawan petri. Kemudian dituangkan PCA steril suhu sekitar $50^{\circ} \mathrm{C}$ sebanyak $15 \mathrm{ml}$. Suspensi dihomogenisasi. Selanjutnya dibiarkan sampai media padat dan diinkubasi dengan suhu $37^{\circ} \mathrm{C}$ selama 2 hari.

\section{Rancangan Penelitian dan Analisa Statistik}

Rancangan penelitian menggunakan Rancangan Acak Lengkap (RAL) dengan satu faktor, yaitu metode pengaplikasian VCO yang terdiri dari K (kontrol), D (pencelupan), dan $\mathrm{S}$ (penyemprotan). Sampel akan diamati selama 12 hari pada hari ke 0, 3, 6, 9 dan 12 di suhu refrigenerator $\left(10 \pm 2^{\circ} \mathrm{C}\right)$. Data hasil penelitian dianalisa statistik dengan metode One Way ANOVA $(\alpha=0,05)$.

\section{HASIL DAN PEMBAHASAN}

\section{Karakteristik Fisik Strawberry}

\section{Susut Bobot}

Tabel 1 menunjukkan bahwa adanya pengaruh penyimpanan terhadap nilai susut bobot buah strawberry. Semakin lama penyimpanan maka nilai susut bobot buah strawberry semakin tinggi. Sari dkk (2015), melaporkan bahwa buah strawberry dikatakan layu bila sudah mengalami kehilangan kadar air mencapai 20\%-24\%. Susut bobot terjadi karena hilangnya komponen air dan volatil lainnya selama proses respiasi dan transpirasi. Sampel buah strawberry dengan perlakuan kontrol memiliki susut bobot yang lebih tinggi. Menurut Winarsih (2018), hal ini terjadi karena $\mathrm{O}_{2}$ masuk dalam buah strawberry sehingga respirasi (penguapan air, gas, dan energi) meningkat.

Tabel 1. Pengaruh VCO Terhadap Susut Bobot Strawberry Selama Penyimpanan Suhu Dingin $\left(10 \pm 2^{\circ} \mathrm{C}\right)$

\begin{tabular}{llllll}
\hline \multirow{2}{*}{\multicolumn{1}{c}{$\mathbf{T}$}} & \multicolumn{5}{c}{ Susut Bobot (\%) Hari ke- } \\
\cline { 2 - 6 } & \multicolumn{1}{c}{$\mathbf{0}$} & \multicolumn{1}{c}{$\mathbf{3}$} & \multicolumn{1}{c}{$\mathbf{6}$} & \multicolumn{1}{c}{$\mathbf{9}$} & $\mathbf{1 2}$ \\
\hline Kontrol & $0,000^{\mathrm{aA}} \pm 0,000$ & $6,93^{\mathrm{bC}} \pm 0,629$ & $12,01^{\mathrm{CB}} \pm 1,227$ & $18,12^{\mathrm{dB}} \pm 1,962$ & $24,23 \% \%^{\mathrm{eC}} \pm 2,427$ \\
Dipping & $0,000^{\mathrm{aA}} \pm 0,000$ & $4,34^{\mathrm{bB}} \pm 0,292$ & $7,45^{\mathrm{CA}} \pm 0,634$ & $11,28^{\mathrm{dA}} \pm 1,039$ & $16,88 \% \%^{\mathrm{eB}} \pm 1,117$ \\
Spraying & $0,000^{\mathrm{aA}} \pm 0,000$ & $2,45^{\mathrm{bA}} \pm 0,125$ & $7,07^{\mathrm{CA}} \pm 0,659$ & $9,16^{\mathrm{dA}} \pm 0,513$ & $12,95 \% \%^{\mathrm{eA}} \pm 0,880$ \\
\hline
\end{tabular}

- Huruf kecil yang sama pada baris yang sama dan huruf besar yang sama pada kolom yang sama menunjukkan tidak berbeda nyata pada taraf signifikansi $(\alpha=0.05)$.

- Huruf kecil menunjukkan perbedaan nilai susut bobot strawberry setiap perlakuan selama penyimpanan. Huruf besar menunjukkan perbedaan nilai susut bobot antar sampel pada setiap hari penyimpanan.

Setelah penyimpanan 12 hari, buah strawberry dengan perlakuan spraying mengalami susut bobot sebesar $12.945 \%$ lebih kecil dibandingkan dengan susut bobot buah strawberry perlakuan dipping, keduanya berbeda nyata pada taraf signifikansi $\alpha=0,05$. Berdasarkan hasil tersebut dapat diketahui bahwa metode pengaplikasian spraying efektif dalam menghambat nilai susut bobot buah strawberry. Valdes et al (2017), pelapisan dengan pengaplikasian penyemprotan (spraying) memiliki kelebihan seperti menghasilkan lapisan yang seragam, dapat mengotrol ketebalan (lebih tipis) dan memungkinkan aplikasi multilayer. Pengaplikasian dengan metode spraying menghasilkan pelapis yang homogen sehingga aditif antimikroba yang ada dapat menyebar dengan cepat kepermukaan yang dilapisi.
Pengaplikasian metode spraying lebih efektif diterapkan pada buah yang memiliki permukaan yang rata seperti pada buah strawberry, apel, mangga dan tomat. Sedangkan pengaplikasian dengan metode dipping lebih efektif diterapkan pada buah yang memiliki permukaan tidak rata seperti buah papaya (Praseptiangga et al., 2016). Menurut Guarav \& Neha (2018), melaporkan pengaplikasian dengan metode dipping dan spraying merupakan dua metode yang umum diaplikasikan pada buah.

\section{Warna}

Semakin lama penyimpanan maka nilai warna buah akan mengalami penurunan. Penurunan ini mengakibatkan warna 
buah strawberry menjadi merah gelap (dark red), hal ini terjadi karena adanya reaksi pencoklatan akibat penurunan stabilitas antosianin pada buah strawberry.

Adanya warna merah pada buah strawberry disebabkan pigmen warna merah yaitu antosianin (Zahroh dkk., 2016). Senyawa $\mathrm{O}_{2}$ yang membentuk terjadinya respirasi menjadikan warna (red) menjadi semakin gelap seiring dengan terjadinya proses pematangan. Kenaikan $\mathrm{pH}$ dalam buah juga mempengaruhi tingkat warna merah pada buah strawberry. Dimana semakin tinggi nilai pH maka semakin rendah warna (red) atau kandungan antosian pada buah (Agustiningrum dkk., 2014).

Menurut Pantastico (1989), kematangan buah ditandai dengan hilangnya warna hijau. Warna hijau pada buah akan berkurang seiring dengan pematangan buah. Klorofilase bertanggung jawab atas perombakan klorofil. Penurunan warna (green) disebabkan karena terjadinya degradasi klorofil (Sumiasih dan Linda, 2016). Warna hijau buah dipengaruhi oleh pigmen klorofil, selama penyimpanan terjadi perombakan klorofil (Iflah dkk., 2012). Penurunan dapat disebabkan karena adanya perubahan warna hijau menjadi warna kuning, orange dan merah.

Warna biru pada buah strawberry menunjukkan adanya kandungan antosianin pada buah, sama seperti warna merah pada buah. Antosianin memiliki pigmen warna merah, biru, dan violet, warna ini banyak dijumpai pada bunga, buahbuahan dan sayuran (Hambali dkk., 2014). Penurunan warna (blue) terjadi karena terjadinya proses pematangan pada buah, sehingga terjadi hidrolisis asam organik menjadi gula. Hal tersebut berkaitan dengan nilai $\mathrm{pH}$ pada buah, dimana ion $\mathrm{H}+$ akan menurun sehingga nilai $\mathrm{pH}$ semakin tinggi (Rachmayati dkk., 2017). Pada suasana basa antosianin akan bewarna violet kemudian biru (Hambali dkk., 2014). Pada penelitian ini pH buah strawberry berkisar 3.333.35 pada hari ke 0 dan hari ke 12 berkisar 3,89-3,91, hal ini menunjukkan buah strawberry masih dalam susana asam.

Pengaplikasian buah strawberry menggunakan VCO memiliki nilai warna yang lebih tinggi dibanding perlakuan kontrol. Hal ini terjadi karena coating VCO pada buah strawberry dapat menghambat masuknya $\mathrm{O}_{2}$ pada buah sehingga warna buah strawberry masih tetap terjaga. Pengaplikasian metode spraying lebih efektif diterapkan pada buah yang memiliki permukaan yang rata seperti pada buah strawberry, apel, mangga dan tomat. Perlakuan metode dipping dan spraying dapat melapisi seluruh permukaan buah strawberry dan memiliki ketebalan lapisan (coating) yang sama. Pori-pori yang terdapat pada buah dapat tertutupi dan sehingga dapat menghambat proses respirasi pada buah (Mahajan et al., 2018).

Tabel 2. Pengaruh VCO Terhadap Warna Strawberry Selama Penyimpanan Suhu Dingin $\left(10 \pm 2^{\circ} \mathrm{C}\right)$

\begin{tabular}{|c|c|c|c|c|c|c|}
\hline \multirow{2}{*}{ W } & \multirow{2}{*}{$\mathbf{T}$} & \multicolumn{5}{|c|}{ Warna Hari ke- } \\
\hline & & 0 & 3 & 6 & 9 & 12 \\
\hline \multirow[t]{3}{*}{ Red } & Kontrol & $192^{\mathrm{bA}} \pm 6.96$ & $178^{\mathrm{bA}} \pm 5.21$ & $148^{\mathrm{bAB}} \pm 5.02$ & $125^{\mathrm{aA}} \pm 3,94$ & $115^{\mathrm{aA}} \pm 4.32$ \\
\hline & Dipping & $229^{\mathrm{CB}} \pm 16.31$ & $193^{\mathrm{bAB}} \pm 14.26$ & $179^{\mathrm{bB}} \pm 3.34$ & $127^{\mathrm{aA}} \pm 10.56$ & $111^{\mathrm{aA}} \pm 2.55$ \\
\hline & Spraying & $218^{\mathrm{d} A \mathrm{~B}} \pm 10.61$ & $199 \mathrm{cB} \pm 11.13$ & $144^{\mathrm{bA}} \pm 5.12$ & $133^{\mathrm{aA}} \pm 7.49$ & $123^{\mathrm{aA}} \pm 8.03$ \\
\hline \multirow[t]{3}{*}{ Green } & Kontrol & $53^{\mathrm{bA}} \pm 5.02$ & $65^{\mathrm{CA}} \pm 1.63$ & $47^{\mathrm{bA}} \pm 2.48$ & $47^{\mathrm{bA}} \pm 0.41$ & $25^{\mathrm{aA}} \pm 1.08$ \\
\hline & Dipping & $55^{\mathrm{bA}} \pm 2.27$ & $85^{\mathrm{cA}} \pm 7.48$ & $54^{\mathrm{bA}} \pm 1.47$ & $56^{\mathrm{bB}} \pm 3.74$ & $32 \mathrm{aB} \pm 0.41$ \\
\hline & Spraying & $58^{\mathrm{cA}} \pm 1.63$ & $82^{\mathrm{dA}} \pm 3.16$ & $43^{\mathrm{bA}} \pm 1.41$ & $49^{\mathrm{bcA}} \pm 2.89$ & $37^{a B} \pm 3.74$ \\
\hline \multirow[t]{3}{*}{ Blue } & Kontrol & $41^{\mathrm{abA}} \pm 3.56$ & $46^{\mathrm{bA}} \pm 3.49$ & $51^{\mathrm{bB}} \pm 2.12$ & $50^{\mathrm{bA}} \pm 1.47$ & $29^{\mathrm{aA}} \pm 2.48$ \\
\hline & Dipping & $57^{\mathrm{bA}} \pm 3.89$ & $71^{\mathrm{cB}} \pm 4.05$ & $56^{\mathrm{bB}} \pm 6.10$ & $61^{\mathrm{bB}} \pm 4.97$ & $40^{\mathrm{aB}} \pm 1.08$ \\
\hline & Spraying & $49^{\mathrm{bA}} \pm 2.45$ & $58^{\mathrm{CAB}} \pm 1.24$ & $40^{\mathrm{aA}} \pm 0.41$ & $53^{\mathrm{bcA}} \pm 2.16$ & $36^{\mathrm{aB}} \pm 3.89$ \\
\hline
\end{tabular}

- Huruf kecil yang sama pada baris yang sama dan huruf besar yang sama pada kolom yang sama menunjukkan tidak berbeda nyata pada taraf signifikansi $(\alpha=0.05)$.

- Huruf kecil menunjukkan perbedaan nilai Warna strawberry setiap perlakuan selama penyimpanan. Huruf besar menunjukkan perbedaan nilai warna antar sampel pada setiap hari penyimpanan.

\section{Firmness}

Tabel 3. Pengaruh VCO Terhadap Firmness Strawberry Selama Penyimpanan Suhu Dingin $\left(10 \pm 2^{\circ} \mathrm{C}\right)$

\begin{tabular}{lccccc}
\hline \multirow{2}{*}{\multicolumn{1}{c}{$\mathbf{T}$}} & $\mathbf{0}$ & $\mathbf{3}$ & \multicolumn{4}{c}{ Firmness $\mathbf{( N )}$ Hari ke- } \\
\cline { 2 - 6 } & $0,949^{\mathrm{CA}} \pm 0,054$ & $1,324^{\mathrm{dB}} \pm 0,117$ & $\mathbf{6}$ & $\mathbf{9}$ & $\mathbf{1 2}$ \\
\hline Kontrol & $1,095^{\mathrm{dB}} \pm 0,044$ & $0,914^{\mathrm{CA}} \pm 0,035$ & $0,975^{\mathrm{CA}} \pm 0,068$ & $0,671^{\mathrm{bA}} \pm 0,034$ & $0,441^{\mathrm{aA}} \pm 0,044$ \\
Dipping & $1,205^{\mathrm{dC}} \pm 0,061$ & $1,043^{\mathrm{CA}} \pm 0,057$ & $1,075^{\mathrm{cA}} \pm 0,070$ & $0,686^{\mathrm{bA}} \pm 0,059$ & $0,512^{\mathrm{aB}} \pm 0,056$ \\
Spraying & $1,20,828^{\mathrm{bB}} \pm 0,035$ & $0,702^{\mathrm{aC}} \pm 0,009$ \\
\hline
\end{tabular}

- Huruf kecil yang sama pada baris yang sama dan huruf besar yang sama pada kolom yang sama menunjukkan tidak berbeda nyata pada taraf signifikansi $(\alpha=0.05)$.

- Huruf kecil menunjukkan perbedaan nilai firmnes strawberry setiap perlakuan selama penyimpanan. Huruf besar menunjukkan perbedaan nilai firmnes antar sampel pada setiap hari penyimpanan.

Secara umum nilai firmness strawberry semakin lama penyimpanan semakin menurun nilai firmnessnya, baik perlakan kontrol maupun coating VCO. Selama penyimpanan buah akan mengalami proses metabolisme menuju proses pematangan. Proses metabolisme tersebut menyebabkan buah kehilangan air, jika air dalam buah berkurang maka sel akan melunak dan terjadilah penurunan nilai firmness (Winarsih, 2018). Pematangan buah terjadi karena adanya proses respirasi dan transpirasi

(Rachmayati dkk., 2017). Nilai firmness buah berkurang karena adanya perubahan pektin pada buah (Pantastico, 1989).

Berdasarkan hasil tersebut buah strawberry perlakuan kontrol mengalami penurunan nilai firmness paling tinggi setelah penyimpanan 12 hari yaitu menjadi 0,4412, sedangkan buah strawberry perlakuan spraying mengalami penurunan nilai firmness paling rendah yaitu menjadi 0,7015 . Hal ini menunjukkan perlakuan coating oil VCO dapat mempertahankan nilai firmness pada buah. Penggunaan pelapisan VCO dapat menghambat tejadinya respirasi pada buah, hal ini terbukti dimana buah strawberry dengan perlakuan kontrol memiliki nilai firmness yang lebih rendah dibanding perlakuan coating oil VCO.

Jika dilihat dari persen penurunan firmness buah strawberry, sampel yang mendapat perlakuan kontrol memiliki penurunan firmness yang lebih besar, dimana perlakuan kontrol memiliki persen penurnan sebesar $52 \%$, $47 \%$ pencelupan (dipping) dan $36 \%$ perlakuan penyeprotan 
(spraying). Buah strawberry yang diberi perlakuan spraying lebih stabil penurunan firmnessnya selama 12 hari penyimpanan. Hasil ini sesuai dengan penelitian Ibrahim et al (2017), melaporkan bahwa nilai firmness buah strawberry penyimpanan suhu $4^{\circ} \mathrm{C}$ tanpa perlakuan pada hari ke 9 sebesar 0,59 $\mathrm{N}$ dan pada hari ke 12 dan 15 mengalami pembusukan, sedangkan buah strawberry perlakuan coating menggunakan kitosan dengan penambahan minyak atsiri serai $1 \%$ dan $2 \%$ mengalami penurunan berkisar antara 0,68 - 0,77 $\mathrm{N}$ dan dengan penambahan thyme oil $1 \%$ dan $2 \%$ berkisar $0,70-0,72 \mathrm{~N}$.

Setelah penyimpanan 12 hari, buah strawberry dengan perlakuan spraying mengalami penurunan firmness sebesar $36 \%$ lebih kecil dibandingkan dengan firmness buah strawberry perlakuan dipping, keduanya berbeda nyata pada taraf signifikansi $\alpha=0,05$. Berdasarkan hasil tersebut dapat diketahui bahwa metode pengaplikasian spraying memberikan perbedaan yang signifikan terhadap nilai firmness buah strawberry. Hal ini ditunjukkan dengan perlakuan spraying lebih efektif dalam mempertahankan nilai tekatur buah strawberry selama 12 hari penyimpanan. Menurut Valdes et al (2017), hal ini terjadi karena metode pengaplikasian penyemprotan (spraying) memberikan lapisan yang seragam, dapat mengontrol ketebalan (lebih tipis), memungkinkan aplikasi multilayer dan spraying menghasilkan pelapis yang homogen sehingga aditif antimikroba yang ada dapat menyebar dengan cepat kepermukaan yang dilapisi. Pengaplikasian metode spraying cenderung lebih efektif diterapkan pada buah yang memiliki permukaan yang rata seperti pada buah strawberry, apel, mangga dan tomat. Sedangkan pengaplikasian dengan metode dipping lebih efektif diterapkan pada buah yang memiliki permukaan tidak rata seperti buah papaya. Pengaplikasian dengan metode dipping dan spraying merupakan dua metode yang umum diaplikasikan pada buah (Prasad et al., 2018). Hasil penelitian ini hampir sama dengan penelitian Praseptiangga et al (2016), melaporkan bahwa nilai firmness buah papaya MJ9 coating dengan metode pengaplikasian dipping dan spraying tidak menunjukkan perbedaan yang signifikan. Buah papaya MJ9 yang diberi pelapis berbahan dasar pati singkong dengan kombinasi minyak atsiri serei $1 \%$ dengan teknik dipping dan spray memberikan hasil berturut-turut 25,52 N dan 25,02 N.

\section{Karakteristik Kimia Strawberry}

\section{Kadar Air}

Tabel 4. Pengaruh VCO Terhadap Kadar Air Strawberry Selama Penyimpanan Suhu Dingin $\left(10 \pm 2^{\circ} \mathrm{C}\right)$

\begin{tabular}{llcccc}
\hline \multirow{2}{*}{\multicolumn{1}{c}{$\mathbf{T}$}} & \multicolumn{5}{c}{ Kadar Air (\%) Hari ke- (\%) } \\
\cline { 2 - 6 } & \multicolumn{1}{c}{$\mathbf{0}$} & $\mathbf{3}$ & $\mathbf{6}$ & $\mathbf{9}$ & $\mathbf{1 2}$ \\
\hline Kontrol & $93,92^{\mathrm{CB}} \pm 0,509$ & $93,920^{\mathrm{CB}} \pm 0,792$ & $92,64^{\mathrm{bB}} \pm 0,360$ & $92,24^{\mathrm{bB}} \pm 0,389$ & $88,82^{\mathrm{aB}} \pm 0,925$ \\
Dipping & $91,46^{\mathrm{bA}} \pm 0,377$ & $91,02^{\mathrm{bA}} \pm 0,616$ & $91,14^{\mathrm{bA}} \pm 1,091$ & $90,25^{\mathrm{bA}} \pm 0,050$ & $86,03^{\mathrm{aA}} \pm 0,548$ \\
Spraying & $92,07^{\mathrm{cA}} \pm 0,077$ & $91,80^{\mathrm{cA}} \pm 0,031$ & $91,77^{\mathrm{cAB}} \pm 0,284$ & $90,88^{\mathrm{bA}} \pm 0,525$ & $86,69^{\mathrm{aA}} \pm 0,469$ \\
\hline
\end{tabular}

- Huruf kecil yang sama pada baris yang sama dan huruf besar yang sama pada kolom yang sama menunjukkan tidak berbeda nyata pada taraf signifikansi $(\alpha=0,05)$.

- Huruf kecil menunjukkan perbedaan nilai kadar air strawberry setiap perlakuan selama penyimpanan. Huruf besar menunjukkan perbedaan nilai kadar air antar sampel pada setiap hari penyimpanan

Semua sempel mengalami penurunan kadar air selama penyimpanan 12 hari. Semakin lama penyimpanan maka kadar air buah akan semakin menurun. Proses pematangan buah mengakibakan penurunan kadar air. Semakin tinggi laju respirasi maka semakin cepat proses transpirasi, sehingga mengakibatkan proses pematangan (Rachmayati dkk., 2017). Proses transpirasi (penguapan air) selama penyimpanan dapat mengakibakan penurunan susut buah serta mempengaruhi firmness buah.

Jika dilihat dari presentase penurunan kadar air, buah strawberry perlakuan kontrol mengalami presentase penurnan sebesar $5,4 \%$, pada buah strawberry perlakuan dipping sebesar 5,9\%, sedangkan buah strawberry perlakuan spraying sebesar $5,8 \%$. Buah strawberry perlakuan dipping dan spraying mengalami presentase penurunan kadar air yang sedikit lebih besar dibanding perlakuan kontrol. Hal ini terjadi karena pada saat proses penguapan air ada beberapa zat yang ikut menguap dan hilang seperti gula mengalami dekomposisi atau karamelisasi dan lemak mengalami oksidasi. Selain itu beberapa kandungan asam lemak yang tedapat pada VCO juga ikut menguap, seperti asam kaprat, asam kaprilat, dan asam kaproat. Beberapa zat yang hilang tersebut dihitung sebagai air.

Variasi metode pengaplikasian pada buah strawberry berpengaruh signifikan terhadap kadar air buah. Hasil uji lanjut DMRT menunjukkan nilai kadar air buah strawberry perlakan kontrol berbeda nyata pada taraf signifikansi $\alpha=0,05$ dengan perlakuan coating VCO pada hari ke 0 sampai hari ke 12 penyimpanan. Pada hari ke 0 kadar air buah strawberry daalam penelitian ini berkisar 91,464. $93,918 \%$, pada hari ke 0 buah dianggap masih segar dan memliki kualitas yang baik. Hasil ini sesuai dengan penelitian Paduret et al (2007), dimana buah strawberry dengan tingkat kematangan ripe (matang) memiliki nilai kadar air berkisar 90-95\%. Hasil ini tidak jauh bereda dengan penelitian Ikrawan dkk (2017), buah strawberry penyimpanan suhu ruang memiliki kadar air 93,36\%. Menurut Budiman dan Saraswati (2008), menjelaskan bahwa buah strawberry memiliki kadar air mencapai $89,9 \%$. Sedangkan berdasarkan USDA nutition fact (2018), kadar air buah strawberry sebesar 90,95 g. Hasil kadar air yang didapatkan lebih besar dari standart USDA. Perbedaan ini terjadi dikarenakan faktor lingkugan seperti daerah tempat penananman, kesuburan tanah, dan jenis tanah (Lase dkk., 2017).

Pada hari ke 12 penyimpanan nilai kadar air buah strawberry berkisar $86,036-88,821 \%$. Hasil ini sesuai dengan penelitian Paduret et al (2007), buah strawberry dengan tingkat kematangan over ripe berkisar $84,2-89,6 \%$. Selama penyimpanan 12 hari Buah strawberry perlakuan dipping memiliki nilai kadar air yang tidak berbeda nyata $(p<0,05)$ dengan kadar air buah strawberry perlakuan spraying. Hal ini menunjukkan perlakuan coating oil VCO dapat mempertahankan kadar air pada buah. Selain itu VCO mampu mengotrol keluarnya gas pada buah seperti $\mathrm{O}_{2}$ dan $\mathrm{CO}_{2}$, sehingga dapat menghambat terjadinya respirasi dan transpirasi (Mahajan et al., 2018). Dilihat dari presentase penurunan perlakuan kontrol sebesar $5,41 \%$, perlakuan dipping sebesar $5,93 \%$ dan perlakuan spraying $5,84 \%$. Hasil tersebut menunjukkan semua sampel memiliki presentase penurunan yang hampir sama.

Setelah penyimpanan 12 hari, buah strawberry dengan perlakuan spraying dan dipping tidak berbeda nyata pada taraf signifikansi $\alpha=0,05$. Berdasarkan hasil tersebut dapat 
diketahui bahwa kedua metode pengaplikasian spraying dan dipping tidak memberikan perbedaan yang signifikan terhadap kadar air buah strawberry. Hal ini diduga perlakuan metode dipping dan spraying dapat melapisi seluruh permukaan buah strawberry dan memiliki ketebalan lapisan coating yang sama. Pori-pori yang terdapat pada buah dapat tertutupi dan sehingga dapat menghambat proses respirasi pada buah. Pengaplikasian metode spraying cenderung lebih efektif diterapkan pada buah yang memiliki permukaan yang rata seperti pada buah strawberry, apel, mangga dan tomat. Sedangkan pengaplikasian dengan metode dipping lebih efektif diterapkan pada buah yang memiliki permukaan tidak rata seperti buah papaya.

\section{Total Padatan Terlarut (TPT)}

Lama penyimpanan berpengaruh signifikan $(p<0,05)$ terhadap nilai total padatan terlarut buah strawberry. Pada buah strawberry perlakuan kontrol mulai mengalami kenaikan nilai TPT pada hari ke 9. Sedangkan pada buah strawberry perlakuan dipping dan spraying cenderung stabil dan mulai mengalami sedikit peningkatan pada hari ke 9 . Meningkatnya nilai TPT buah strawberry sesuai dengan pernyataan Lase dkk (2017), bahwa buah yang mengalami kenaikan nilai TPT menunjukkan terjadinya poses pematangan. Buah strawberry perlakuan dipping menunjukkan penurunan yang cenderung sedikit, sedangkan pada perlakuan spraying nilai TPT buah strawberry cenderug tetap dan tidak mengalami penurunan. Berdasarkan Tabel 5 tersebut buah strawberry perlakuan kontrol memiliki nilai total padatan terlarut paling tinggi setelah penyimpanan 12 hari yaitu sebesar $5,47{ }^{\circ}$ Brix, sedangkan buah strawberry perlakuan spraying memiliki nilai total padatan terlarut paling rendah yaitu sebesar $5,13^{\circ}$ Brix. Setelah penyimpanan 12 hari, buah strawberry dengan perlakuan spraying relatif stabil yaitu sebesar $5,13{ }^{\circ}$ Brix. Hasil total padatan terlarut perlakuan spraying lebih kecil dibandingkan dengan total padatan terlarut buah strawberry perlakuan dipping, namun keduanya tidak berbeda nyata pada taraf signifikansi $\alpha=0,05$. Berdasarkan hasil tersebut dapat diketahui bahwa metode pengaplikasian dipping dan spraying memberikan perbedaan yang signifikan terhadap nilai total padatan terlarut buah strawberry. Hal ini diduga perlakuan metode dipping dan spraying dapat melapisi seluruh permukaan buah strawberry dan memiliki ketebalan lapisan coating yang sama.

Tabel 5. Pengaruh VCO Terhadap Total Padatan Terlarut Strawberry Selama Penyimpanan Suhu Dingin $\left(10 \pm 2^{\circ} \mathrm{C}\right)$

\begin{tabular}{lccccc}
\hline \multirow{1}{*}{\multicolumn{1}{c}{ T }} & \multicolumn{5}{c}{ Total Padatan Terlarut ( ${ }^{\circ}$ Brix) Hari Ke - } \\
\cline { 2 - 6 } & $\mathbf{0}$ & $\mathbf{3}$ & $\mathbf{6}$ & $\mathbf{9}$ & $\mathbf{1 2}$ \\
\hline Kontol & $5,03^{\mathrm{aA}} \pm 0,058$ & $5,02^{\mathrm{aA}} \pm 0,029$ & $5,03^{\mathrm{aA}} \pm 0,058$ & $5,67^{\mathrm{bB}} \pm 0,306$ & $5,47^{\mathrm{abAB}} \pm 0,503$ \\
Dipping & $5,03^{\mathrm{aA}} \pm 0,058$ & $5,00^{\mathrm{aA}} \pm 0,000$ & $5,12^{\mathrm{aA}} \pm 0,104$ & $5,30^{\mathrm{aA}} \pm 0,300$ & $5,20^{\mathrm{aA}} \pm 0,200$ \\
Spraying & $5,03^{\mathrm{aA}} \pm 0,058$ & $5,13^{\mathrm{aA}} \pm 0,115$ & $5,03^{\mathrm{aA}} \pm 0,058$ & $5,13^{\mathrm{aA}} \pm 0,230$ & $5,13^{\mathrm{aA}} \pm 0,115$ \\
\hline
\end{tabular}

- Huruf kecil yang sama pada baris yang sama dan huruf besar yang sama pada kolom yang sama menunjukkan tidak berbeda nyata pada taraf signifikansi $(\alpha=0,05)$.

- Huruf kecil menunjukkan perbedaan nilai total padatan terlarut strawberry setiap perlakuan selama penyimpanan. Huruf besar menunjukkan perbedaan nilai total padatan terlarut antar sampel pada setiap hari penyimpanan.

Menurut Prasad et al (2018), melaporkan pengaplikasian dengan metode dipping dan spraying merupakan dua metode yang umum diaplikasikan pada buah. Pengaplikasian metode spraying cenderung lebih efektif diterapkan pada buah yang memiliki permukaan yang rata seperti pada buah strawberry, apel, mangga dan tomat. Sedangkan pengaplikasian dengan metode dipping lebih efektif diterapkan pada buah yang memiliki permukaan tidak rata seperti buah papaya. Hasil penelitian ini sama dengan penelitian Praseptiangga (2016) dan Husnawati (2016), melaporkan bahwa nilai TPT buah papaya MJ9 coating dengan metode pengaplikasian dipping dan spraying tidak menunjukkan perbedaan yang signifikan. Buah papaya MJ9 yang diberi pelapis berbahan dasar pati singkong dengan kombinasi minyak atsiri serei $1 \%$ dengan teknik dipping dan spraying pada hari ke 12 memberikan hasil berturut-turut 10,45 ${ }^{\circ}$ Brix dan 10,55 ${ }^{\circ}$ Brix, sedangkan coating berbahan dasar pektin dengan kombinasi minyak atsiri serei $1 \%$ dengan teknik dipping dan spraying pada hari ke 12 memberikan hasil berturut-turut 9,375 ${ }^{\circ}$ Brix dan $10,375^{\circ}$ Brix. Buah papaya MJ9 yang diberi pelapis berbahan dasar pati singkong tanpa kombinasi dengan teknik dipping dan spraying pada hari ke 12 berturut-turut sebesar 10,78 ${ }^{\circ}$ Brix dan $10,73^{\circ}$ Brix, sedangkan coating berbahan dasar pektin tanpa kombinasi dengan teknik dipping dan spraying pada hari ke 12 memberikan hasil berturut-turut $10,350^{\circ}$ Brix dan $10,500^{\circ}$ Brix.

\section{Vitamin C}

Semakin lama penyimpanan maka nilai vitamin $C$ buah akan mengalami penurunan. Penurunan kadar vitamin terjadi karena terjadinya proses metabolisme yaitu peruraian asam-asam organic (Lase dkk., 2017). Penurunan asam asam organik terjadi karena proses pematangan dan proses respirasi pada buah. Proses pematangan menyebabkan meningkatnya rasa manis pada buah, sehingga rasa sepat dan masam menjadi berkurang (Pantastico, 1989). Buah strawberry perlakuan kontrol mengalami penurunan kadar vitamin $\mathrm{C}$ paling tinggi setelah penyimpanan 12 hari yaitu menjadi $47,250 \%$.

Berdasarkan Tabel 6, buah strawberry perlakuan kontrol mengalami penurunan kadar vitamin $\mathrm{C}$ paling tinggi setelah penyimpanan 12 hari yaitu menjadi $47,250 \%$, sedangkan buah strawberry perlakuan spraying mengalami penurunan nilai vitamin $\mathrm{C}$ paling rendah yaitu menjadi $52,633 \%$. Buah strawberry perlakuan dipping memiliki kadar vitamin $\mathrm{C}$ yang tidak berbeda nyata $(p<0,05)$ dengan kadar vitamin $C$ buah strawberry perlakuan spraying. Hal ini disebabkan karena pemberian pelapisan pada buah strawberry berupa VCO dapat menghambat terjadinya respirasi pada buah serta menutupi pori-pori pada buah. Sehingga O2 disekitar tidak dapat masuk ke dalam jaringan buah. Menurut Lase dkk (2017), buah strawberry yang diberi perlakuan pelapisan memiliki susut buah yang lebih rendah. Hal ini membuat buah strawberry kehilangan air yang lebih sedikit sehingga kandungan vitamin $\mathrm{C}$ dapat dipertahankan.

Tabel 6. Pengaruh VCO Terhadap Vitamin C Strawberry Selama Penyimpanan Suhu Dingin $\left(10 \pm 2^{\circ} \mathrm{C}\right)$

\begin{tabular}{cccccc}
\hline \multirow{2}{*}{$\mathbf{T}$} & $\mathbf{5}$ Vitamin C (\%) Hari ke- \\
\cline { 2 - 6 } & $\mathbf{0}$ & $\mathbf{3}$ & $\mathbf{6}$ & $\mathbf{9}$ & $\mathbf{1 2}$ \\
\hline Kontrol & $63,06^{\mathrm{bA}} \pm 2,462$ & $62,73^{\mathrm{bA}} \pm 1,867$ & $53,07^{\mathrm{aA}} \pm 4,403$ & $52,03^{\mathrm{aA}} \pm 5,236$ & $47,25^{\mathrm{aA}} \pm 3,729$ \\
Diping & $62,95^{\mathrm{bA}} \pm 3,620$ & $60,15^{\mathrm{bA}} \pm 2,659$ & $58,69^{\mathrm{bA}} \pm 1,943$ & $52,90^{\mathrm{aA}} \pm 1,016$ & $50,36^{\mathrm{aA}} \pm 1,186$ \\
\hline
\end{tabular}




\begin{abstract}
Spaying $\quad 63,32^{\mathrm{bA}} \pm 2,810 \quad 62,60^{\mathrm{bA}} \pm 1,505 \quad 58,70^{\mathrm{abA}} \pm 5,310 \quad 58,20^{\mathrm{abA}} \pm 5,375 \quad 52,63^{\mathrm{aA}} \pm 4,789$
- Huruf kecil yang sama pada baris yang sama dan huruf besar yang sama pada kolom yang sama menunjukkan tidak berbeda nyata pada taraf signifikansi $(\alpha=0.05)$.

- Huruf kecil menunjukkan perbedaan nilai vitamin C strawberry setiap perlakuan selama penyimpanan. Huruf besar menunjukkan perbedaan nilai vitamin $\mathrm{C}$ antar sampel pada setiap hari penyimpanan.
\end{abstract}

Setelah penyimpanan 12 hari, buah strawberry dengan perlakuan spraying kadar vitamin $\mathrm{C}$ sebesar $52,633 \%$ lebih besar dibandingkan dengan kadar vitamin $\mathrm{C}$ buah strawberry perlakuan dipping yaitu sebesar $50.355 \%$. Keduanya tidak berbeda nyata pada taraf signifikansi $\alpha=0,05$. Berdasarkan hasil tersebut dapat diketahui bahwa kedua metode pengaplikasian spraying dan dipping tidak memberikan perbedaan yang signifikan terhadap nilai vitamin $\mathrm{C}$ buah strawberry. Hal ini diduga perlakuan metode dipping dan spraying dapat melapisi seluruh permukaan buah strawberry dan memiliki ketebalan lapisan coating yang sama. Pori-pori yang terdapat pada buah dapat tertutupi dan sehingga dapat menghambat proses respirasi pada buah.

\section{pH}

Semakin lama penyimpanan maka buah strawberry mengalami peningkatan nilai $\mathrm{pH}$. Buah strawberry varietas Elsanta pada penelitian Paduret et al (2017), pH buah strawberry dengan tingkat kematanan nearly ripe nilai $\mathrm{pH}$ sebesar 3,81 dan pada tingkat kematanan over ripe nilai $\mathrm{pH}$ sebesar 4,01. Kenaikan $\mathrm{pH}$ pada buah menunjukkan terjadinya proses pematangan pada buah. Hal ini terjadi karena hidrolisis asam yang terjadi saat proses pematangan (Rachmayati dkk., 2017). Nilai pH sangat berkaitan dengan nilai TPT dan total asam buah.
Variasi metode pengaplikasian pada buah strawberry berpengaruh signifikan terhadap nilai $\mathrm{pH}$ buah pada penyimpanan hari ke 0 dan 6 . Hasil uji lanjut DMRT menunjukkan pada hari ke 0 terjadi perbedaan nilai $\mathrm{pH}$ yang signifikan antara perlakuan kontrol dengan coating VCO. Hal ini ditunjukkan dengan nilai $\mathrm{pH}$ buah strawberry perlakan kontrol sedikit lebih tinggi dibanding buah strawberry perlakuan coating VCO. Pada hari ke 0 buah strawberry dianggap masih segar dan nilai $\mathrm{pH}$ buah strawberry pada penelitian ini berkisar 3,33-3,35. Nilai $\mathrm{pH}$ buah strawberry awal dalam penelitian ini sesuai dengan penelitian Akhtar dan Abdur (2015) dimana buah strawberry segar memiliki nilai $\mathrm{pH}$ berkisar $3,10-3,40$. Hasil $\mathrm{pH}$ penelitian ini sesuai dengan teori Green (1971), melaporkan bahwa nilai pH buah strawberry pada semua kultivar berkisar 3,41 dan 3,72, ratarata nilai $\mathrm{pH}$ buah strawberry matang yaitu 3,3 . Pada hari ke 3 nilai $\mathrm{pH}$ buah strawberry dengan metode pengaplikasian coating VCO menunjukkan hasil yang tidak berbeda nyata denan nilai $\mathrm{pH}$ perlakuan kontrol. Namun, pada hari ke 6 penyimpanan nilai $\mathrm{pH}$ buah strawberry perlakuan dipping lebih besar signifikan dibanding perlakuan kontrol. Pada penyimpanan hari ke 9 buah strawberry kembali menunjukkan hasil yang tidak berbeda nyata antar perlakuan pada taraf signifikan $\alpha=0,05$ sampai hari ke 12 penyimpanan.

Tabel 7. Pengaruh VCO Terhadap pH Strawberry Selama Penyimpanan Suhu Dingin $\left(10 \pm 2^{\circ} \mathrm{C}\right)$

\begin{tabular}{lccccc}
\hline \multirow{2}{*}{$\mathbf{T}$} & $\mathbf{5}$ & $\mathbf{p H}$ Hari Ke - \\
\cline { 2 - 6 } & $\mathbf{0}$ & $\mathbf{3}$ & $\mathbf{6}$ & $\mathbf{9}$ & $\mathbf{1 2}$ \\
\hline Kontrol & $3,35^{\mathrm{aB}} \pm 0,005$ & $3,47^{\mathrm{bA}} \pm 0,044$ & $3,65^{\mathrm{CA}} \pm 0,090$ & $3,64^{\mathrm{CA}} \pm 0,069$ & $3,89^{\mathrm{dA}} \pm 0,033$ \\
Dipping & $3,33^{\mathrm{AA}} \pm 0,013$ & $3,46^{\mathrm{bA}} \pm 0,012$ & $3,76^{\mathrm{CB}} \pm 0,016$ & $3,70^{\mathrm{CA}} \pm 0,097$ & $3,93^{\mathrm{dA}} \pm 0,068$ \\
Spraying & $3,34^{\mathrm{aAB}} \pm 0,010$ & $3,52^{\mathrm{bA}} \pm 0,040$ & $3,73^{\mathrm{CAB}} \pm 0,015$ & $3,71^{\mathrm{CA}} \pm 0,093$ & $3,91^{\mathrm{dA}} \pm 0,034$ \\
\hline
\end{tabular}

- Huruf kecil yang sama pada baris yang sama dan huruf besar yang sama pada kolom yang sama menunjukkan tidak berbeda nyata pada taraf signifikansi $(\alpha=0.05)$.

- Huruf kecil menunjukkan perbedaan nilai $\mathrm{pH}$ strawberry setiap perlakuan selama penyimpanan. Huruf besar menunjukkan perbedaan nilai $\mathrm{pH}$ antar sampel pada setiap hari penyimpanan.

Nilai $\mathrm{pH}$ buah strawberry perlakuan kontrol lebih rendah yaitu 3,89 dibanding perlakuan dipping dan spraying. Berdasarkan hasil uji DMRT menunjukkan bahwa perlakuan dipping dan spraying tidak berbeda nyata dengan perlakuan kontrol. Penerapan coating oil VCO bertujuan untuk menghambat terjadinya respirasi dan transpirasi. Sesuai yang dijelaskan oleh teori Mahajan et al (2018), VCO merupakan salah satu coating oil yang berbasis lipid. Pelapis berbasis lipid dapat mencegah kehilangan air dan mencegah adanya respirasi, sehingga dapat memperpanjang umur simpan buah. Menurut Nasrin et al (2018), melaporkan bahwa penggunaan VCO sebagai pelapis dapat mempertahankan $\mathrm{pH}$ pada buah jeruk mandarin. Pada hari ke 0 nilai $\mathrm{pH}$ buah jeruk mandarin sebesar 4,1 setelah peyimpanan 16 hari nilai $\mathrm{pH}$ tetap stabil yaitu sebesar 4,1 .

Berdasarkan hasil tersebut, setelah 12 hari penyimpanan, nilai $\mathrm{pH}$ buah strawberry dengan perlakuan dipping dan spraying tidak berbeda nyata dengan nilai $\mathrm{pH}$ buah strawberry perlakuan kontrol pada taraf signifikansi $\alpha=0,05$. Buah strawberry dengan perlakuan spraying nilai $\mathrm{pH}$ sebesar 3,91 lebih kecil dibandingkan dengan nilai $\mathrm{pH}$ buah strawberry perlakuan dipping yaitu sebesar 3,93. Keduanya tidak berbeda nyata pada taraf signifikansi $\alpha=0,05$. Berdasarkan hasil tersebut dapat diketahui bahwa kedua metode pengaplikasian spraying dan dipping tidak memberikan perbedaan yang signifikan terhadap nilai $\mathrm{pH}$ buah strawberry. Hal ini diduga perlakuan metode dipping dan spraying dapat melapisi seluruh permukaan buah strawberry dan memiliki ketebalan lapisan coating yang sama. Pori-pori yang terdapat pada buah dapat tertutupi dan sehingga dapat menghambat proses respirasi pada buah.

\section{Total Asam Terlaut (TAT)}

Lama penyimpanan berpengaruh signifikan $(p<0,05)$ terhadap nilai total asam tertitrasi. Semua sempel mengalami penurunan nilai total asam tertitrasi selama penyimpanan 12 hari. Penurunan asam organik pada buah selama penyimpanan karena proses respirasi atau perubahan asam organik menjadi gula sederhana. Sel buah menggunakan asam organik sebagai substrat untuk respirasi (Sudjatha dan Ni Wayan, 2017). Penurunan asam - asam organik terjadi karena proses pematangan yang terjadi selama penyimpanan (Pantastico, 1989).

Variasi metode pengaplikasian pada buah strawberry berpengaruh signifikan terhadap nilai TAT buah pada hari ke 0 dan 3 penyimpanan. Hasil uji lanjut DMRT menunjukkan pada hari ke 0 penyimpanan nilai TAT buah strawberry perlakuan dipping lebih tinggi signifikan dibanding perlakuan kontrol. Nilai TAT dalam penelitian ini selaras dengan nilai $\mathrm{pH}$ buah strawberry. Hasil ini sesuai dengan pernyataan Zahroh dkk (2016), bahwa nilai pH berbanding terbalik dengan total asam, dimana kenaikan $\mathrm{pH}$ menunjukkan terjadinya penurunan pembentukan asam buah. Pada hari ke 3 penyimpanan buah strawberry perlakuan dipping 
berbeda nyata dengan buah strawberry perlakuan kontrol, ditunjukkan dengan nilai TAT perlakuan kontrol lebih besar. Setelah penyimpanan hari ke 6 , pengaplikasian coating VCO buah strawberry menunjukkan hasil yang tidak berbeda nyata pada taraf signifikansi $\alpha=0,05$ dengan perlakuan kontrol terhadap nilai TAT buah strawberry. Nilai TAT buah strawberry perlakuan kontrol lebih rendah yaitu $8 \%$ dibanding perlakuan dipping dan spraying. Hal ini menunjukkan perlakuan coating oil VCO cukup dapat mempertahankan nilai TAT pada buah. Hal ini menunjukkan perlakuan coating oil VCO dapat mempertahankan nilai TAT pada buah. Hal ini disebabkan karena pemberian pelapisan pada buah strawberry berupa VCO dapat menghambat terjadinya respirasi pada buah serta menutupi pori-pori pada buah. Sehingga $\mathrm{O}_{2}$ disekitar tidak dapat masuk ke dalam jarigan buah.

Tabel 8. Pengaruh VCO Terhadap Total Asam Tertitrasi Strawberry Selama Penyimpanan Suhu Dingin $\left(10 \pm 2^{\circ} \mathrm{C}\right)$

\begin{tabular}{lccccc}
\hline \multirow{1}{*}{ T } & \multicolumn{5}{c}{ Total Asam Warna (\%) Hari ke- } \\
\cline { 2 - 6 } & $\mathbf{0}$ & $\mathbf{3}$ & $\mathbf{6}$ & $\mathbf{9}$ & $\mathbf{1 2}$ \\
\hline Kontrol & $19 \%^{\mathrm{dA}} \pm 0.010$ & $13 \%^{\mathrm{CB}} \pm 0.008$ & $10 \%^{\mathrm{bA}} \pm 0.003$ & $11 \%^{\mathrm{bA}} \pm 0.003$ & $8 \% \%^{\mathrm{aA}} \pm 0.008$ \\
Dipping & $21 \%^{\mathrm{CB}} \pm 0.008$ & $11 \%^{\mathrm{bA}} \pm 0.007$ & $11 \%^{\mathrm{bA}} \pm 0.003$ & $11 \%^{\mathrm{bA}} \pm 0.008$ & $9 \%^{\mathrm{aA}} \pm 0.003$ \\
Spraying & $20 \%^{\mathrm{dAB}} \pm 0.006$ & $12 \%^{\mathrm{CAB}} \pm 0.008$ & $11 \%^{\mathrm{bcA}} \pm 0.006$ & $10 \%^{\mathrm{abA}} \pm 0.009$ & $9 \%^{\mathrm{aA}} \pm 0.007$ \\
\hline
\end{tabular}

- Huruf kecil yang sama pada baris yang sama dan huruf besar yang sama pada kolom yang sama menunjukkan tidak berbeda nyata pada taraf signifikansi $(\alpha=0.05)$.

- Huruf kecil menunjukkan perbedaan nilai TAT strawberry setiap perlakuan selama penyimpanan. Huruf besar menunjukkan perbedaan nilai TAT antar sampel pada setiap hari penyimpanan.

Berdasarkan hasil tersebut buah strawberry perlakuan kontrol memiliki nilai total asam tertitrasi paling rendah setelah penyimpanan 12 hari yaitu sebesar $8 \%$, sedangkan buah strawberry perlakuan spraying dan dipping memiliki nilai total padatan terlarut sebesar $9 \%$. Berdasarkan hasil tersebut dapat diketahui bahwa metode pengaplikasian dipping dan spraying tidak memberikan perbedaan yang signifikan terhadap nilai TAT buah strawberry, keduanya tidak berbeda nyata pada taraf signifikansi $\alpha=0,05$. Hal ini diduga metode pengapikasian dipping dan spraying mempunyai kemampuan yang sama yaitu dapat melapisi seluruh permukaan buah strawberry dan memiliki ketebalan lapisan coating yang sama. Pori-pori yang terdapat pada buah dapat tertutupi dan sehingga dapat menghambat proses respirasi pada buah.

\section{Karakteristik Mikrobiologi Strawberry}

\section{Total Plate Count (TPC)}

Buah strawberry memiliki lapisan kulit yang tipis, apabila terjadi kerusakan atau memar dibagian kulit dapat memicu timbulnya mikroba, sehingga buah cepat busuk. Buah yang telah mengalami kerusakan ditandai dengan munculnya jamur pada permukaan, mengkerut, dan firmness menjadi lunak. Penyakit busuk pada buah strawberry disebabkan oleh jamur dan bakteri. Lama penyimpanan berpengaruh signifikan $(p<0,05)$ terhadap total mikroba. Semua sempel mengalami peningkatan total mikroba selama penyimpanan 12 hari. Total mikroba perlakuan kontrol lebih besar dibanding perlakuan dipping dan spraying. Hal ini disebabkan karena kandungan nutrisi dan air dalam buah digunakan untuk media pertumbuhan mikroba. Nilai total asam buah berbanding terbalik dengan total mikroba. Penurunan total asam disebabkan karena penggunaan asam organik untuk proses respirasi dan pertumbuhan mikroba. Energi dan nutrisi pada buah termasuk asam organik digunakan mikroba untuk tumbuh dan berkembang, sehingga total asam pada buah menurun (Alexandra dan Nurlina., 2014). Menurut peraturan E.C. (No. 2073/2005) dalam Delgadu et al (2013), total mikroba yang telah melampaui 6 log CFU/ml merupakan batas akhir umur simpan buah strawberry.

Tabel 9. Pengaruh VCO Terhadap TPC Strawberry Selama Penyimpanan Suhu Dingin $\left(10 \pm 2^{\circ} \mathrm{C}\right)$

\begin{tabular}{lccccc}
\hline \multirow{2}{*}{\multicolumn{1}{c}{$\mathbf{T}$}} & $\mathbf{5}$ & $\mathbf{3}$ & $\mathbf{6}$ & $\mathbf{9}$ & $\mathbf{1 2}$ \\
\cline { 2 - 6 } & $3,96^{\mathrm{aA}} \pm 0,140$ & $4,32^{\mathrm{aB}} \pm 0,101$ & $5,50^{\mathrm{bA}} \pm 0,518$ & $5,54^{\mathrm{bA}} \pm 0,297$ & $6,28^{\mathrm{CA}} \pm 0,101$ \\
Kontrol & $4,10^{\mathrm{aA}} \pm 0,291$ & $4,13^{\mathrm{aAB}} \pm 0,178$ & $5,23^{\mathrm{bA}} \pm 0,142$ & $5,35^{\mathrm{bA}} \pm 0,093$ & $5,59^{\mathrm{bA}} \pm 0,525$ \\
Dipping & $3,91^{\mathrm{aA}} \pm 0,186$ & $3,91^{\mathrm{aA}} \pm 0,239$ & $5,25^{\mathrm{bA}} \pm 0,203$ & $5,34^{\mathrm{bA}} \pm 0,381$ & $5,42^{\mathrm{bA}} \pm 0,531$ \\
Spraying & &
\end{tabular}

- Huruf kecil yang sama pada baris yang sama dan huruf besar yang sama pada kolom yang sama menunjukkan tidak berbeda nyata pada taraf signifikansi $(\alpha=0.05)$.

- Huruf kecil menunjukkan perbedaan nilai TPC strawberry setiap perlakuan selama penyimpanan. Huruf besar menunjukkan perbedaan nilai TPC antar sampel pada setiap hari penyimpanan.

Hasil tersebut mengindikasikan bahwa buah strawberry yang diberi perlakuan VCO dapat menghambat pertumbuhan mikroba pada buah strawberry selama 12 hari penyimpanan. Medium Chain Fatty Acids (MCFA) atau lemak jenuh yang terkandung dalam VCO dapat menghancurkan oeganisme mikroba dengan merombak membran. Asam laurat diketahui dapat menghambat pertumbuhan beberapa jenis mikroba seperti Eschercia coli, Pseudomonas aerugenosa, dan Bacillus subtiilis (Nasir et al., 2017). Senyawa asam laurat yang terdapat pada VCO dirubah menjadi senyawa monogliserida yakni monolaurin. Monolaurin merupakan senyawa yang bersifat antivirus, antibakteri, dan antijamur. Monolaurin dapat merusak membran lipid (lapisan pembungkus virus). Senyawa monolaurin dapat mematikan beberapa jenis bakteri seperti Staphylococcusaureus, Helieobacterpylori (Rindengan, 2006). Selain itu VCO dapat menghambat bakteri gram positif seperti Staphyllococcus aureus, S. epidermis,
Mycobacterium tuberculosis, Nocardia asteroids, Salmonella typhimurium, dan Helicobacter pylori (Widiyanti, 2015).

\section{KESIMPULAN}

Virgin Coconut Oil (VCO) memberi pengaruh yang nyata terhadap karakteristik fisik kimia dan mikrobiologi strawberry selama penyimpanan. Selama penyimpanan peggunaan VCO dapat memertahankan susut bobot, warna, Firmness, kadar air, vitamin C, pH, TAT (Total Asam Tertitrasi) serta dapat menurukan nilai TPT (Total Padatan Terlarut) dan TPC. Metode pengaplikasian VCO pada strawberry dengan variasi perlakuan terhadap total mikroba tidak berbeda signifikan selama penyimpanan, dimana metode dipping dan spraying efektif dalam menghambat pertumbuhan mikroba pada strawberry selama 12 hari penyimpanan. 


\section{DAFTAR PUSTAKA}

(AOAC) Association of Official Analytical Chemist. (2005). Official Methods of Analysis $16^{\text {th }}$ Edition. Association of Official Analytical Chemist inc. AOAC Inc, Arlington. Virginia.

(AOAC) Association of Official Analytical Chemist. (2012). Official Methods of Analysis $16^{\text {th }}$ Edition. Association of Official Analytical Chemist inc. AOAC Inc, Arlington. Virginia

Agustiningrum, Dyah Ayu, Bambang Susilo, dan Rini Yulianingsih. 2014. Studi pengaruh konsentrasi oksigen pada penyimpanan atmosfer termodifikasi buah sawo (Achras zapota L.). Jurnal Bioproses Komoditas Tropis Vol. 2(1): 22-34.

Akhtar, ljaz and Abdur Rab. 2015. Effect Of Fruit Ripening Stages On Strawberry (Fragaria $X$ Ananassa. Duch) Fruit Quality For Fresh Consumption. J. Agric. Res., Vol. 53(3): 413-424.

Alexandra, Yongki dan Nurlina. (2014). Aplikasi Edible Coating Dari Pektinjeruk Songhi Pontianak (Citrus nobilis var Microcarpa) Pada Penyimpanan Buah Tomat. JKK Vol 3(4): 11-20 I, SSN 2303-10771.

Andi, N.A. 2005. Virgin Coconut Oil Minyak Penakluk Aneka Penyakit. Tangerang:Pt Agromedia Pustaka.

Bisen, Abhay, Sailendra K. P and Neha P. 2012. Effect of skin coatings on prolonging shelf life of kagzi lime fruits (Citrus aurantifolia Swingle). J Food Sci Technol 49(6):753-759.

Budiman, Supriatin dan Desi Saraswati. 2008. Berkebun Stroberi secara Komersial. Penebar Swadaya. Jakarta.

Delgadu, Sergio Nogales, Ana Maria Fernandez Leon, And Jonathan Delgado Adamez, Maria Teresa Hernandez Mendez, Dan Diego Bohoyo Gil. 2013. Effects Pf Several Sanitisers For Improving Quality Attributes Of Minimally Processed Fragaria vesca Strawberry. Czech J. Food Sci. Vol (31)1: 49-54.

Fardiaz, S. 1993. Analisis Mikrobiologi Pangan. Edisi Pertama. Cetakan Pertama. Raja Grafindo Persada, Jakarta.

Garcia, Lorena Costa, Leila Mendes Pereira, Claire I. G. de Luca Sarantópoulos dan Miriam Dupas Hubinger. 2010. Selection of an Edible Starch Coating for Minimally Processed Strawberry. Food Bioprocess Technol

Hambali, Mulkan, Febrilia M., dan Fitriadi N. (2014). Ekstraksi Antosianin Dari Ubi Jalar Dengan Variasi Konsentrasi Solven, Dan Lama Waktu Ekstraksi. Jurnal Teknik Kimia Vol 2(2): 25-35.

Hanif, Zainuri dan Huriin H. (2014). Perbandingan Atribut Mutu Buah Stroberi Yang Beredar Di Pasar Tradisional Dan Modern Di Malang Dan Yogyakarta. Prosiding Seminar Nasional Perhorti : 469-476

Ibrahim MA, Sharoba AM2, El Waseif KH1, El Mansy HA2 and El Tanahy HH. 2017. Effect of Edible Coating by Chitosan with Lemongrass and Thyme Oils on Strawberry Quality and Shelf Life during Storage. Journal Food Technol Nutr Sci, Vol 3(1):1-11.

Iflah T, Sutrisno, dan T C Sunarti. (2012). Pengaruh Kemasan Starch-Based Plastics (Bioplastik) terhadap Mutu Tomat dan Paprika Selama Penyimpanan Dingin. Jurnal Teknologi Industri Pertanian Vol.22 (3): 183-197.

Ikrawan, Dr. Ir. Yusep, M.Eng., Ir. Hj. Ina Siti Nurminabari, Mp., dan Kiki Isma Agniati. 2017. Kajian Pengaruh Jenis Pelapis Dan Suhu Pengeringan Terhadap Sifat Fisika Dan Kimia Buah Stroberi (Fragraria Sp) Selama Penyimpanan. Bandung: Fakultas Teknik Universitas Pasundan.
Kamboj, Prince and Amarjeet Kaur. (2018). Influence of Various Oil Coatings on the Shelf Life of Guava cv. Allahabad Safeda. Int. J. Pure App. Biosci. Vol.6 (3): 650-657.

Kore, Vijaykumar T., Sima S. Tawade and J. Kabir. (2017). Application of Edible Coatings on Fruits and Vegetables. Imperial Journal of Interdisciplinary Research (IJIR) Vol. 3(1):591-603.

Krochta, J.M. (1992). Control of Mass Transfer in Food with Edible Coatings and Films, In : Singh, R.P. \& M.A. Wirakartakusumah (Eds) : Advances in Food Engineering. CRC Press : Boca Raton, pp. 517-53.

Kurnia A. (2005). Stroberi. Jakarta: Gramedia.

Lase, Desnoviani Putri Utami, Rona J. Nainggolan, dan Elisa J. (2017). Pemanfaatan Pati Ubi Jalar Merah Sebagai Edible Coating Dan Pengaruhnya Terhadap Mutu Strawberry Selama Penyimpanan. J.Rekayasa Pangan dan Pert., Vol.5 No.3.

Lerdthanangkul, Sirichit and John M. Krochta. (1996). Edible Coating Effects on Postharvest Quality of Green Bell Peppers. Journal Of Food Science Vol. 61(1): 176-179.

Mahajan, Bal Vipan Chander, Ritu Tandon, Swati Kapoor and Mohinder Kaur Sidhu. 2018. Natural Coatings for Shelf-Life Enhancement and Quality Maintenance of Fresh Fruits and Vegetables - A Review. Journal of Postharvest Technology Vol 06(1): 12-26.

Nasir, Nur Ainatul Mardia Mohamad, Zurainie Abllah, Anil Azura Jalaludin, Intan Azura Shahdan, and Wan Nor Hayati Wan Abd Manan. 2017. Virgin Coconut Oil and Its Antimicrobial Properties against Pathogenic Microorganisms: A Review. Advances in Health Science Research, Vol: 8: 192-198.

Nasrin, T.A.A., M.N. Islam, M.A. Rahman, M.S. Arfin and M.A. Ullah. (2018). Evaluation Of Postharvest Quality Of Edible Coated Mandarin At Ambient Storage. Int. J. Agril. Res. Innov. \& Tech. Vol : 8 (1): 18-25 ISSN: 22240616.

Pantastico, ER.B. (1989). Fisiologi Pasca Panen. Gajah Mada University Press.

Prasad K, Abhay Kumar Guarav, Preethi P and Pallavi Neha. 2018. Edible Coating Technology for Extending Market Life of Horticultural Produce. Journal Acta Scientific Agriculture (ISSN: 2581-365X) Vol.2 (5):55-64.

Praseptiangga, D, R Utami, L U Khasanah, I P Evirananda, and Kawiji. 2016. Effect Of Cassava Starch-Based Edible Coating Incorporated With Lemongrass Essential Oil On The Quality Of Papaya MJ9. IOP Conf. Series: Materials Science and Engineering 176

Rachmayati, Hani, Wahono H. S, dan Jaya M. M. (2017). Pengaruh Tingkat Kematangan Buah Belimbing (Averrhoa carambola L.) Dan Proporsi Penambahan Gula Terhadap Karakteristik Fisik, Kimia Dan Organoleptik Jelly Drink Mengandung Karaginan. Jurnal Pangan dan Agroindustri Vol. 5(1): 49-60.

Rindengan dan Novarianto, (2006). Virjin Coconut Oil: Pembuatan dan Pemanfaatan. Seri Agritekno. Penerbar Swadaya.

Sari, Rita Nopita, Dwi D. N, dan Cicih S. (2015). Pengaruh Konsentrasi Tepung Karagenan Dan Gliserol Sebagai Edible Coating Terhadap Perubahan Mutu Buah Stroberi (Fragaria $X$ Ananassa) Selama Penyimpanan. Jurnal Teknik Pertanian LampungVol. 4(4): 305-314.

Singh, Harjinder, Dilip Singh Kachwaya, Venkata Satish Kuchi, Ghumare Vika, Naveet Kaushal and Ajay Singh. (2017). Edible Oil Coatings Prolong Shelf Life and Improve Quality of Guava. Int. J. Pure App. Biosci. Vol. 5 (3): 837-843.

Sudjatha, W dan Ni Wayan Wisaniyasa. 2017. Fisiologi dan Teknologi Pasca Panen. Udayana Universitas Press. 
Sumiasih, Inanpi Hidayati, Linda Octaviani, Dessy Indah Lestari, dan Endah Ratna Yunita. (2016). Studi Perubahan Kualitas Pascapanen Buah Belimbing Dengan Beberapa Pengemasan Dan Suhu Simpan. Jurnal Agrin Vol. 20(2):115-124, ISSN: 1410-0029.

USDA. 2018. Basic Report 09316, Strawberry, Raw. USDA National Nutrient Database for Standard Reference. The National Agricultural Library.

Valdes, Arantzazu, Marina Ramos, Ana Beltrán, Alfonso Jiménez and María Carmen Garrigós. 2017. State of the Art of Antimicrobial Edible Coatings for Food Packaging Applications. Analytical Chemistry, Nutrition \& Food Sciences Department, University of Alicante page: 1-23.

Widiyanti, Rahma Ayu. 2015. Pemanfaatan Kelapa Menjadi Vco (Virgin Coconut Oi) Sebagai Antibiotik Kesehatan Dalam Upaya Mendukung Visi Indonesia Sehat 2015. Prosiding Seminar Nasional Pendidikan Biologi, Prodi Pendidikan Biologi FKIP Universitas Muhammadiyah Malang : 577-584

Widiyanti, Rahma Ayu. 2015. Pemanfaatan Kelapa Menjadi Vco (Virgin Coconut Oil) Sebagai Antibiotik Kesehatan Dalam Upaya Mendukung Visi Indonesia Sehat 2015. Prosiding Seminar Nasional Pendidikan Biologi, Prodi Pendidikan Biologi FKIP Universitas Muhammadiyah Malang : 577-584.

Winarno, F.G dan M. Aman. 2004. Fisiologi Lepas Panen. Sustra Hudaya, Bogor.

Winarsih, Sri. 2018. Pengawetan Strawberry (Fragaria ananassa) Menggunakan Edible Coating Berbasis Pektin Dari Cincau Hijau (Cylea barbata). Jurnal IImuIImu Pertanian "AGRIKA", Vol 12(2): 108-117.

Zahroh, Sakinah Ummu, Rohula Utami, dan Godras Jati Manuhara. 2016. Penggunaan Kertas Aktif Berbasis Oleoresin Ampas Jahe Emprit (Zingiber officinale var. amarum) Terhadap Kualitas Buah Stroberi (Fragaria $x$ ananassa) Selama Penyimpanan. Journal of Sustainable Agriculture, Vol. 31 (1): 59-70. 